\title{
Kettapeptin: Isolation, Structure Elucidation and Activity of a New Hexadepsipeptide Antibiotic from a Terrestrial Streptomyces sp.
}

\author{
Rajendra P. Maskey, Serge Fotso, Madhumati Sevvana, Isabel Usón, Iris Grün-Wollny, \\ Hartmut Laatsch
}

Received: March 13, 2006 / Accepted: May 17, 2006

(C) Japan Antibiotics Research Association

\begin{abstract}
The ethyl acetate extract of the Streptomyces sp. isolate GW99/1572 exhibited significant biological activity against Gram-positive bacteria and delivered kettapeptin (1), a new hexadepsipeptide antibiotic of the azinothricin type. The structure was elucidated by various 1D and 2D NMR techniques, mass spectrometry and by comparison of the NMR data with those of closely related antibiotics. The absolute configuration of the compound was derived by crystal structure analysis and by comparison with the optical rotation data of related compounds.
\end{abstract}

Keywords kettapeptin, peptide lactone, antibiotic, cytotoxic, azinothricin

\section{Introduction}

Cyclic hexadepsipeptides of the azinothricin type are characterised by a 19-membered cyclodepsipeptide ring composed of 6 unusual amino acids and an acyl side chain connected through an amide bond. The first member of this class, azinothricin (2) was reported from Streptomyces $\mathrm{X}-14950$ in 1986 [1]. These antibiotics exhibit strong

H. Laatsch (Corresponding author), R. P. Maskey, S. Fotso: Department of Organic \& Biomolecular Chemistry, University of Göttingen, Tammanstrasse 2, D-37077 Göttingen, Germany,

E-mail: hlaatsc@gwdg.de

M. Sevvana, I. Usón: Department of Inorganic Chemistry, University of Göttingen, Tammanstrasse 4, D-37077 Götingen, Germany

I. Grün-Wollny: Labor Grün-Wollny, Versaillerstr. 1, D-35394 Giessen, Germany antitumor and antibacterial activity against Gram-positive bacteria [2 4]. Many of them show activity against peptic and duodenal ulcer [5]. Additionally, they are known to promote wound healing [6], and have antiinflammatory activity [7].

In our screening program of streptomycetes for new novel antibiotics, the ethyl acetate extract of the strain Streptomyces sp. isolate GW99/1572 exhibited biological activity against the bacteria Bacillus subtilis, Escherichia coli, and Streptomyces viridochromogenes, the fungi Candida albicans and Mucor miehei and the micro-alga Scenedesmus subspicatus. Responsible for the antifungal

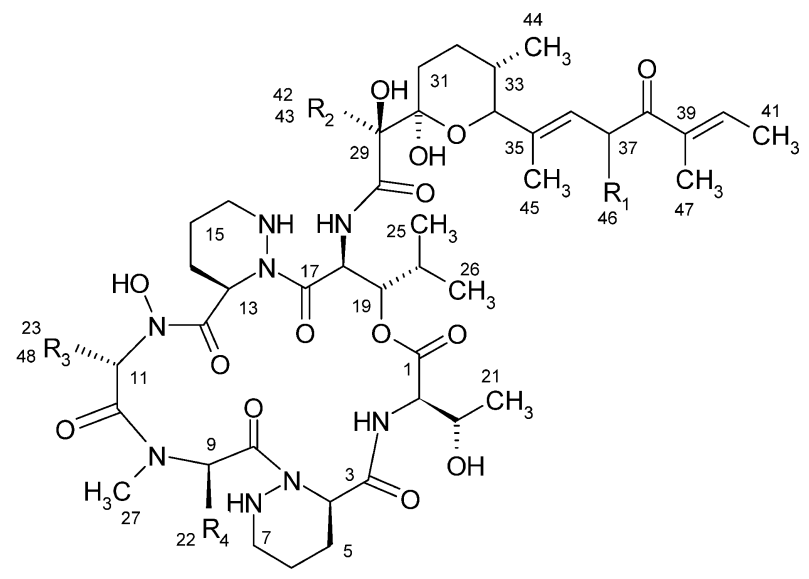

1: $\mathrm{R}^{1}=\mathrm{R}^{4}=\mathrm{CH}_{3} ; \mathrm{R}^{2}=\mathrm{CH}_{2} \mathrm{CH}_{3} ; \mathrm{R}^{3}=\mathrm{CH}_{2} \mathrm{OCH}_{3}$

2: $\mathrm{R}^{1}=\mathrm{R}^{2}=\mathrm{CH}_{2} \mathrm{CH}_{3} ; \mathrm{R}^{3}=\mathrm{CH}_{2} \mathrm{OCH}_{3} ; \mathrm{R}^{4}=\mathrm{CH}_{3}$

3: $\mathrm{R}^{1}=\mathrm{R}^{3}=\mathrm{R}^{4}=\mathrm{CH}_{3} ; \mathrm{R}^{2}=\mathrm{CH}_{2} \mathrm{CH}_{3}$

4: $\mathrm{R}^{1}=\mathrm{R}^{2}=\mathrm{R}^{3}=\mathrm{CH}_{3} ; \mathrm{R}^{4}=\mathrm{CH}_{2} \mathrm{CH}\left(\mathrm{CH}_{3}\right)_{2}$

5: $\mathrm{R}^{1}=\mathrm{R}^{2}=\mathrm{CH}_{3} ; \mathrm{R}^{3}=\mathrm{CH}_{2} \mathrm{OCH}_{3} ; \mathrm{R}^{4}=\mathrm{CH}_{2} \mathrm{CH}\left(\mathrm{CH}_{3}\right)_{2}$ 
activity was a complex mixture (ESI MS) of yellow polar antibiotics that were identified as carbonyl-conjugated polyene macrolides by UV/VIS, NMR data, and the brown colour reaction with concentrated sulphuric acid; these compounds were not further characterised. In addition, a colourless weakly UV absorbing TLC band was detected which gave a violet colouration with anisaldehyde/ sulphuric acid. In a bio-autogram, the band was shown to be responsible for the anti-microbial activity mentioned above. Work-up of the extract guided by biological activity and chemical screening resulted in the isolation of a new hexadepsipeptide antibiotic that we name kettapeptin (1). In this paper, we report on the taxonomy of the producing strain and the isolation, structure elucidation and biological activity of the new antibiotic.

\section{Results and Discussion}

The terrestrial Streptomyces sp. isolate GW99/1572 was cultivated in $\mathrm{M}_{2}$ medium using our standard conditions [8]. The crude extract resulting from ethyl acetate extraction was subjected to column chromatography on silica gel using a $\mathrm{CH}_{2} \mathrm{Cl}_{2} / \mathrm{MeOH}$ gradient and separated into two fractions. Further purification of the more polar fraction using preparative TLC and Sephadex LH-20 afforded kettapeptin (1) in a yield of $4 \mathrm{mg}$ per liter of fermentation.

Kettapeptin (1) was obtained as a colourless solid. The colour with the chlorine/tolidine reaction and the negative ninhydrin test indicated it to be an $N$-terminal blocked peptide. The positive and negative ESI spectra showed quasi-molecular ion peaks at $\mathrm{m} / z 1029\left([\mathrm{M}+\mathrm{Na}]^{+}\right)$and $1005\left([\mathrm{M}-\mathrm{H}]^{-}\right)$, respectively. This was consistent with the molecular weight of $1006\left(\mathrm{C}_{48} \mathrm{H}_{78} \mathrm{~N}_{8} \mathrm{O}_{15}\right.$ by HRMS $)$. The IR spectrum contained an ester band at $v 1744 \mathrm{~cm}^{-1}$ and amide bands at $v 1667,1650$ and $1636 \mathrm{~cm}^{-1}$. The complex ${ }^{1} \mathrm{H}$ NMR spectrum delivered eight signals of acidic protons and at least six $\alpha$-methine protons of amino acids between $\delta 6.13$ and 4.54 , characteristic of peptides. It also showed two olefinic proton signals at $\delta 6.74$ and 5.63 as indicated by HSQC correlations. In addition to many other methine and methylene proton signals, the spectrum depicted twelve methyl signals, an $O$ - and an $N$-methyl singlet, an olefinic methyl doublet, two olefinic methyl singlets, and five doublets and a triplet for methyl groups connected to $s p^{3}$ carbon atoms. With the aid of ${ }^{1} \mathrm{H}-{ }^{1} \mathrm{H}$ COSY couplings, an ethyl and an isopropyl residue were identified. The search with these spectroscopic data in AntiBase [9] did not reveal a structure that matched the NMR data, the molecular weight and the empirical formula of $\mathbf{1}$. However, the search uncovered hexadepsipeptides with similar analytical data: azinothricin [1] (2), A83586C [10] (3), GE3 (4) [2] and citropeptin [11] (5). The similarity of the NMR data with those of $\mathbf{2} \sim \mathbf{5}$ indicated that the isolated compound might be a related cyclopeptidelactone.

The ${ }^{13} \mathrm{C}$ and APT NMR spectra of kettapeptin (1) depicted 48 carbon signals. It contained, in addition to a signal at $\delta 203.0$ of a conjugated ketone, seven amide carbonyl signals between $\delta 175.3 \sim 169.5$. In the $s p^{2}$ carbon region, two quaternary and two methine carbon signals were detected. Signals for a quaternary acetal carbon at $\delta$ 99.6 and a quaternary carbon atom bearing oxygen at $\delta$ 80.1 were visible in the spectrum. Ten methylene carbon signals were also observed: one with an oxygen atom, two bearing nitrogen atoms and the residuals connected only to $s p^{3}$ carbon atoms. The spectrum also contained six $\alpha$ methine carbons of amino acids between $\delta$ 56.2 47.7, three signals for $\mathrm{CH}$ groups connected to oxygen and three more methine signals at $\delta 38.2,32.5$ and 29.2. In addition, twelve methyl signals included one $O$-methyl, one $N$ methyl and nine of $C$-methyl groups. Careful interpretation of the ${ }^{1} \mathrm{H}$ and ${ }^{13} \mathrm{C}$ NMR data and ${ }^{1} \mathrm{H}-{ }^{1} \mathrm{H}$ COSY, HSQC and HMBC couplings resulted in an acyl substructure (Fig. 1) and a cyclic peptide backbone (Fig. 2). The HMBC coupling of 18-CH and 18-NH of the peptide substructure (Fig. 2) to the carbonyl carbon of the acyl side chain (Fig. 2) connected both fragments to give the final planer structure of kettapeptin (1).

NOE effects between $45-\mathrm{H}_{3}$ and $46-\mathrm{H}_{3}$ as well as $41-\mathrm{H}_{3}$ and $47-\mathrm{H}_{3}$ indicated a trans,trans-configuration of the double bonds in the side chain. The coupling constant of $J=10 \mathrm{~Hz}$ between $33-\mathrm{H}(\delta 1.48)$ and $34-\mathrm{H}(\delta$ 3.98) indicated these protons to be in an axial position. The NOE couplings of 30-OH with $42-\mathrm{H}_{2}, 43-\mathrm{H}_{3}$ and $34-\mathrm{H}$ and of 34$\mathrm{H}$ with $44-\mathrm{H}_{3}$ and the similarity of the ${ }^{1} \mathrm{H}$ and ${ }^{13} \mathrm{C}$ data of the respective proton and carbon atoms with those of $\mathbf{2} \sim \mathbf{5}$ suggested a relative configuration of the tetrahydropyranyl part as in $\mathbf{2} \sim \mathbf{5}$. The ${ }^{1} \mathrm{H}$ chemical shift of $37-\mathrm{H}(\delta 4.09)$ and $46-\mathrm{H}_{3}(\delta 1.14)$ and the ${ }^{13} \mathrm{C}$ data of $\mathrm{C}-37(\delta 38.2)$ and $\mathrm{C}-46$ $(\delta 19.5)$ of 1 were very similar to those of GE3 $(4 ; 37-\mathrm{H}: \delta$ $\left.4.06 ; 46-\mathrm{H}_{3}: \delta 1.12 ; \mathrm{C}-37: \delta 38.5 ; \mathrm{C}-46: \delta 19.2\right), \mathrm{A} 83586 \mathrm{C}$ (3; 37-H: $\delta 4.09 ; 46-\mathrm{H}_{3}: \delta 1.12 ; \mathrm{C}-37: \delta 38.3$; C-46: $\delta$ 19.6) and citropeptin $\left(5 ; 37-\mathrm{H}: \delta 4.07 ; 46-\mathrm{H}_{3}: \delta 1.12\right.$; C-37: $\delta$ 38.0; C-46: $\delta$ 18.8) and indicated that the acyl substructure possessed the same relative configuration, related conformations anticipated.

As kettapeptin (1) crystallized easily from acetone, a crystal structure analysis was performed (1) which indeed confirmed our assumption: The relative configuration of $\mathbf{1}$ derived from the NMR data (Table 1) and the crystal analysis (Fig. 3) is identical to those of $\mathbf{2} \sim \mathbf{5}$. As also the specific rotation $\left([\alpha]_{\mathrm{D}}^{20}=+111.2^{\circ}\right)$ of $\mathbf{1}$ is very similar to 
Table $1{ }^{1} \mathrm{H}(600 \mathrm{MHz})$ and ${ }^{13} \mathrm{C}(150 \mathrm{MHz}) \mathrm{NMR}$ data of kettapeptin $(\mathbf{1})$ in $\mathrm{CDCl}_{3}(\delta$; $J$ in $\mathrm{Hz})$

\begin{tabular}{|c|c|c|c|c|c|}
\hline C No. & ${ }^{13} \mathrm{C}$ NMR & ${ }^{1} \mathrm{H} N M R$ & C No. & ${ }^{13} \mathrm{C}$ NMR & ${ }^{1} \mathrm{H} N M R$ \\
\hline 1 & $170.2 \mathrm{~s}$ & - & 24 & $29.2 d$ & $1.68(\mathrm{~m})$ \\
\hline 2 & $56.2 \mathrm{~d}$ & $4.54(d, 8.6)$ & 25 & $19.3 q$ & $0.72(d, 7.1)$ \\
\hline 3 & $169.5 \mathrm{~s}$ & - & 26 & $14.6 \mathrm{q}$ & $0.83(d, 6.8)$ \\
\hline 4 & $52.4 \mathrm{~d}$ & $5.20(\mathrm{dd}, 5.6,1.5)$ & 27 & $29.4 \mathrm{q}$ & 3.06 (s) \\
\hline 5 & $24.4 \mathrm{t}$ & $2.58(\mathrm{~m}), 1.72(\mathrm{~m})$ & 28 & $175.3 \mathrm{~s}$ & - \\
\hline 6 & $21.3 t$ & $1.64(\mathrm{~m}), 1.54(\mathrm{~m})$ & 29 & $80.1 \mathrm{~s}$ & - \\
\hline 7 & $48.0 \mathrm{t}$ & $3.30(\mathrm{~d}, 13.2), 2.58(\mathrm{~m})$ & $29-\mathrm{OH}$ & - & $2.95(\mathrm{~s})$ \\
\hline $7-\mathrm{NH}$ & - & $3.87(\mathrm{~m})$ & 30 & $99.6 \mathrm{~s}$ & - \\
\hline 8 & $173.1 \mathrm{~s}$ & - & $30-\mathrm{OH}$ & - & 6.29 (s) \\
\hline 9 & $47.7 d$ & $6.13(q, 7.0)$ & 31 & $28.3 t$ & $1.72(\mathrm{~m})$ \\
\hline 10 & $171.0 \mathrm{~s}$ & - & 32 & $27.2 \mathrm{t}$ & $1.52(\mathrm{~m})$ \\
\hline 11 & $53.8 d$ & $5.34(t, 7.1)$ & 33 & $32.5 d$ & $1.48(\mathrm{~m})$ \\
\hline $11-\mathrm{NOH}$ & - & $9.96(\mathrm{~s})$ & 34 & $82.2 \mathrm{~d}$ & $3.98(d, 10.0)$ \\
\hline 12 & $172.8 \mathrm{~s}$ & & 35 & $132.8 \mathrm{~s}$ & - \\
\hline 13 & $51.3 d$ & $4.92(\mathrm{~m})$ & 36 & $129.3 d$ & $5.63(d d, 9.1,0.7)$ \\
\hline 14 & $24.0 t$ & $2.26(\mathrm{~d}, 13.4), 1.88(\mathrm{~m})$ & 37 & $38.2 \mathrm{~d}$ & $4.09(\mathrm{dq}, 8.9,6.9)$ \\
\hline 15 & $21.1 \mathrm{t}$ & $1.54(\mathrm{~m}), 1.48(\mathrm{~m})$ & 38 & $203.0 \mathrm{~s}$ & - \\
\hline 16 & $45.6 t$ & $3.17(\mathrm{~d}, 12.8), 2.98(\mathrm{~m})$ & 39 & $137.5 \mathrm{~s}$ & - \\
\hline $16-\mathrm{NH}$ & - & $4.44(\mathrm{dd}, 12.2,1.6)$ & 40 & $136.8 d$ & $6.74(q, 6.9)$ \\
\hline 17 & $170.8 \mathrm{~s}$ & & 41 & $14.9 q$ & $1.86(\mathrm{~m})$ \\
\hline 18 & $54.6 \mathrm{~d}$ & $4.92(\mathrm{~m})$ & 42 & $25.9 t$ & $2.04(\mathrm{~m}), 1.66(\mathrm{~m})$ \\
\hline $18-\mathrm{NH}$ & - & $8.24(d, 10.7)$ & 43 & $8.4 \mathrm{q}$ & $0.86(t, 7.6)$ \\
\hline 19 & $78.6 \mathrm{~d}$ & $5.42(\mathrm{dd}, 10.7,2.1)$ & 44 & $17.6 \mathrm{q}$ & $0.71(d, 6.2)$ \\
\hline 20 & $64.7 \mathrm{~d}$ & $4.80(q, 6.5)$ & 45 & $12.0 \mathrm{q}$ & 1.59 (s) \\
\hline $20-\mathrm{OH}$ & - & 4.37 (s) & 46 & $19.5 q$ & $1.14(q, 6.8)$ \\
\hline 21 & 18.9 q & $1.07(d, 6.5)$ & 47 & $11.4 \mathrm{q}$ & 1.78 (s) \\
\hline 22 & $13.1 \mathrm{q}$ & $1.26(d, 7.0)$ & 48 & $59.2 q$ & $3.37(\mathrm{~s})$ \\
\hline 23 & $68.5 \mathrm{t}$ & $3.87(\mathrm{~m}), 3.76(\mathrm{dd}, 10.0,6.7)$ & & & \\
\hline
\end{tabular}

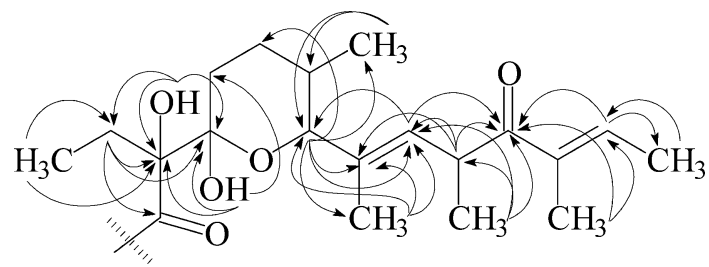

Fig. 1 Structure of the acyl rest of kettapeptin (1) derived by $\operatorname{HMBC}(\rightarrow)$ correlations.

that of azinothricin $\left(2,[\alpha]_{\mathrm{D}}^{25}=+117.65^{\circ}\right)[1], \mathrm{A} 83586 \mathrm{C}(\mathbf{3}$, $\left.[\alpha]_{\mathrm{D}}^{25}=+116.1^{\circ}\right)[10], \operatorname{GE} 3\left(4,[\alpha]_{\mathrm{D}}^{25}=+111.5^{\circ}\right)[2]$, and citropeptin $\left(5,[\alpha]_{\mathrm{D}}^{25}=+113.0^{\circ}\right)[11]$, also the absolute configuration of 1 should be identical with that of $\mathbf{2} \sim \mathbf{5}$. The peptide lactone part of kettapeptin (1) is identical with that of azinothricin (2) and very similar to those of A83586C (3), GE3 (4) and citropeptin (5). Kettapeptin (1) is the 37-nor-derivative of azinothricin (2).

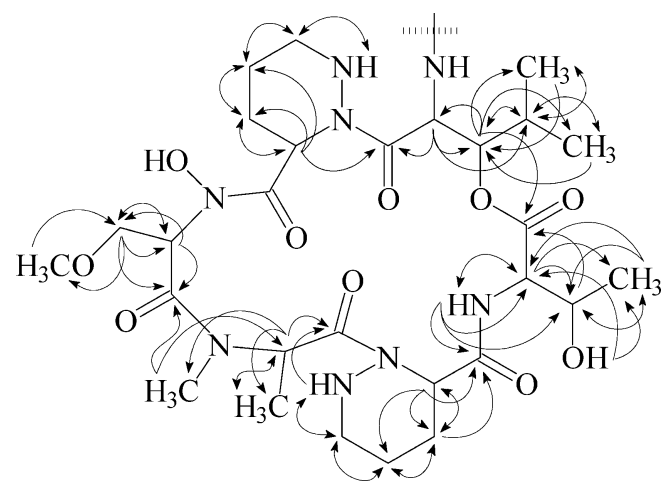

Fig. 2 Structure of the peptide chain of kettapeptin (1) derived by ${ }^{1} \mathrm{H}-{ }^{1} \mathrm{H}$ COSY $(\leftrightarrow)$ and $\mathrm{HMBC}(\rightarrow)$ correlations.

\section{Biological Activity}

Antibacterial, antifungal and antialgal activities were semiquantitatively determined using the agar diffusion method with $9 \mathrm{~mm}$ paper discs and $0.1 \sim \mu \mathrm{g}$ of kettapeptin 
Table 2 Physicochemical properties of kettapeptin (1)

\begin{tabular}{ll}
\hline \multicolumn{1}{c}{ Appearance } & \multicolumn{1}{c}{ Colourless crystals (from acetone) } \\
\hline $\mathrm{Rf}\left(\mathrm{CH}_{2} \mathrm{Cl} / 5 \% \mathrm{MeOH}\right)$ & 0.35 \\
Molecular formula & $\mathrm{C}_{48} \mathrm{H}_{78} \mathrm{~N}_{8} \mathrm{O}_{15}$ \\
$(+)-\mathrm{ESI} \mathrm{MS}: \mathrm{m} / \mathrm{z}(\%)$ & $1029\left([\mathrm{M}+\mathrm{Na}]^{+}, 100\right), 1051\left([\mathrm{M}+2 \mathrm{Na}-\mathrm{H}]^{+}, 8\right)$ \\
$(-)$-ESI MS: $\mathrm{m} / \mathrm{z}(\%)$ & $1027\left([\mathrm{M}+\mathrm{Na}-2 \mathrm{H}]^{-}, 20\right), 1005\left([\mathrm{M}-\mathrm{H}]^{-}, 100\right)$ \\
$\mathrm{ESI} \mathrm{HRMS}$ & $1006.5617(\mathrm{calcd} .1006 .558664)$ \\
$\mathrm{IR}(\mathrm{KBr}): v \mathrm{~cm}^{-1}$ & $3422,2955,2938,1744,1667,1650,1636,1504,1458,1394$, \\
& $1352,1318,1260,1208,1148,1118,1069,998,912,869,818$, \\
{$[\alpha]_{D}^{20}\left(c 1.0, \mathrm{CHCl}_{3}\right)$} & 728,686 \\
\hline
\end{tabular}

(a)

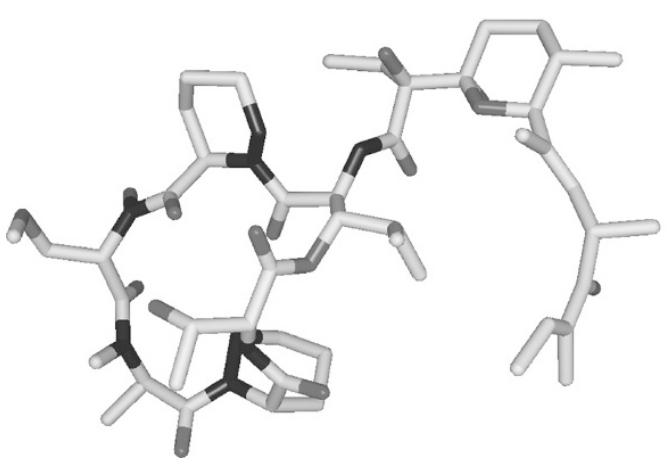

(b)

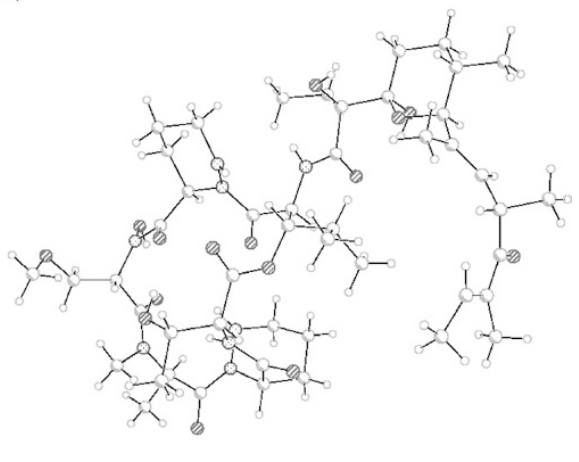

Fig. 3 Crystal structure of kettapeptin (1) (a) without and (b) with the hydrogen atoms

Table 3 Antibacterial activities of kettapeptin (1) and bacitracin A in agar diffusion test (i.d. of inhibition zones, $\mathrm{mm}$ )

\begin{tabular}{|c|c|c|c|c|c|}
\hline Compounds & Amount ( $\mu \mathrm{g} / \mathrm{disk})$ & $\mathrm{BS}^{\mathrm{a}}$ & $S V^{b}$ & $S A^{c}$ & $E C^{d}$ \\
\hline \multirow[t]{5}{*}{ Kettapeptin (1) } & 0.1 & 0 & & & \\
\hline & 1 & 10 & & & \\
\hline & 5 & 13 & 16 & 20 & 12 \\
\hline & 10 & 14 & 16 & 17 & 13 \\
\hline & 20 & 16 & 16 & 16 & 13 \\
\hline \multirow[t]{3}{*}{ Bacitracin A } & 5 & 0 & 0 & 0 & 0 \\
\hline & 10 & 11 & 0 & 11 & 0 \\
\hline & 20 & 14 & 0 & 12 & 11 \\
\hline
\end{tabular}

${ }^{\text {a }}$ Bacillus subtilis, ${ }^{\text {b }}$ Streptomyces viridochromogenes (Tü 57), c Staphylococcus aureus, ${ }^{\text {d }}$ Escherichia coli.

(1)/disk using bacitracin A as a standard. Kettapeptin (1) exhibited activity against Bacillus subtilis, Streptomyces viridochromogenes (Tü 57), Staphylococcus aureus and Escherichia coli, which proved to be much better than that of bacitracin A (Table 3); the MIC value against Bacillus subtilis was determined as $3.75 \mu \mathrm{g} / \mathrm{ml}$. The compound showed no activity against Candida albicans, Mucor miehei, and the microalgae Chlorella vulgaris, Chlorella sorokiniana, and Scenedesmus subspicatus.

In addition to the antibacterial activity, kettapeptin (1) 
was found to be highly active against human cancer cell lines LXFA 629L and LXFL 529L (lung cancer), MAXF 401NL (breast tumor), MEXF 462NL (melanoma), RXF 944L (kidney tumor) and UXF 1138L (uterus tumor) [12] with $\mathrm{IC}_{70}$ value of $<0.6 \mu \mathrm{g} / \mathrm{ml}$.

\section{Experimental}

\section{Materials and Methods}

NMR spectra were measured on a Varian Inova 600 $(600 \mathrm{MHz})$ spectrometer. ESI-MS was recorded on a Quattro Triple Quadrupole Mass Spectrometer, Finnigen TSQ 7000 with nano-ESI-API-ion source. ESI HRMS were measured on Micromass LCT mass spectrometer coupled with a HP 1100 HPLC with a Diode Array Detector. Reserpin $(\mathrm{MW}=608)$ and leucin-enkephalin $(\mathrm{MW}=555)$ were used as standards in positive and negative mode. IR spectra were recorded on a Perkin-Elmer 1600 Series FT-IR spectrometer as $\mathrm{KBr}$ pellets. UV-VIS spectra were recorded on a Perkin-Elmer Lambda 15 UV/VIS spectrometer. Flash chromatography was carried out on silica gel $(230 \sim 400$ mesh). Thin layer chromatography (TLC) were performed on Polygram SIL G/UV 254 (Macherey-Nagel \& Co.). Rf values were measured on Polygram SIL G/UV 254 (Macherey-Nagel \& Co.). Size exclusion chromatography was done on Sephadex LH-20 (Pharmacia). The X-ray structure analysis was performed at $100 \mathrm{~K}$ using a Bruker rotating anode X-ray source operating at $\mathrm{Cu} K \alpha$ radiation (1.5418 $\AA$ wavelength), equipped with osmic focussing mirrors, Bruker platform goniometer and a Bruker SMART $6000 \mathrm{CCD}$ detector.

\section{Taxonomy}

Actinomycete strain GW99/1572 was obtained from the strain collection of Labor Grün-Wollny, Giessen, Germany, where it is maintained. The bacterium was Gram-positive, non-acid fast, grew aerobically, and differentiated into substrate and aerial mycelium. The aerial hyphae were highly branched with long straight to flexous spore chains. Neither aerial nor substrate mycelium showed fragmentation.

The colour of the aerial mycelium was firstly light grey and turned later into green on yeast extract - malt, oatmeal and soil extract agar. The substrate mycelium was light brown on these media. A light orange diffusible pigment was formed on yeast extract - malt extract agar and on soil extract agar. Melanin pigments were not produced on tyrosine agar slants.

The diaminopimelic acid isomer and the sugar composition of the whole cell hydrolysate indicated that the strain had cell walls of type I and belongs to the genus Streptomyces.

\section{Fermentation, Extraction and Isolation}

With a well grown agar culture of the terrestrial Streptomyces sp. isolate GW99/1572, one hundred 1 litreErlenmeyer flasks each containing $250 \mathrm{ml}$ of $\mathrm{M}_{2}$ medium $(10 \mathrm{~g}$ malt extract, $4 \mathrm{~g}$ yeast extract and $4 \mathrm{~g}$ glucose in 11 of tap water was set to $\mathrm{pH} 7.8$ with $2 \mathrm{~N} \mathrm{NaOH}$ and sterilized for 30 minutes at $121^{\circ} \mathrm{C}$ ) were inoculated and incubated for 4 days at $28^{\circ} \mathrm{C}$ on a linear shaker $(110 \mathrm{rpm})$. The culture broth was mixed with $c a .1 \mathrm{~kg}$ of diatomaceous earth and filtered through a press filter to separate mycelium and water phase. The mycelial cake and the filtrate were separately extracted each three times with ethyl acetate ( $c a .2$ litres each). Since the chemical compositions of both organic phases were similar, they were combined and concentrated under reduced pressure to yield $4.7 \mathrm{~g}$ of a yellow oily crude extract.

The crude extract was then subjected to column chromatography on silica gel $(3 \times 200 \mathrm{~cm}, 200 \mathrm{~g})$ with a dichloromethane - methanol gradient and separated into two fractions (I and II) using TLC to monitor the separation. The first fraction contained a complex mixture of hydroxylated polyenemacrolides and was not further analysed. The second fraction exhibited the antibacterial activity and contained a colourless band on TLC, which turned to light violet with anisaldehyde/sulphuric acid. Purification of the fraction by preparative TLC $(20 \times 20 \mathrm{~cm}$, $\left.\mathrm{CH}_{2} \mathrm{Cl}_{2} / 7 \% \mathrm{MeOH}\right)$ followed by final purification on Sephadex LH-20 $\left(\mathrm{CH}_{2} \mathrm{Cl}_{2} / 60 \% \mathrm{MeOH}\right)$ delivered $110 \mathrm{mg}$ of kettapeptin (1) as a colourless solid.

\section{Crystal Structure Analysis}

Kettapeptin crystallized from acetone as needles in the orthorhombic space group $\mathrm{P} 22_{1} 2_{1} 2_{1}$ with a single molecule in the asymmetric unit. For data collection, the crystal was shock frozen in a cold nitrogen stream using perfluoropolyether oil as cryoprotectant.

The data reduction was performed using SAINT (Version 6.05, Bruker AXS 1997-1999) and the data were corrected semiempirically for absorption and other effects with SADABS [13]. The phase problem was solved by conventional direct methods using SHELXS [14] and the model was refined against $\mathrm{F}^{2}$ on all data by full-matrix least-squares with SHELXL [15]. All non-hydrogen atoms were refined anisotropically. All hydrogen atoms were included at geometrically calculated positions.

Crystal data: $\mathrm{C}_{48} \mathrm{H}_{78} \mathrm{~N}_{8} \mathrm{O}_{15}+1 \mathrm{CH}_{3} \mathrm{COCH}_{3}$, crystal size: $0.2 \mathrm{~mm} \times 0.1 \mathrm{~mm} \times 0.05 \mathrm{~mm}$, space group $\mathrm{P} 2{ }_{1} 2{ }_{1} 2_{1}$, unit cell $\mathrm{a}=9.780$ (2) $\AA, \mathrm{b}=20.355$ (4) $\AA, \mathrm{c}=28.635$ (6) $\AA, \alpha=\beta=\gamma$ 
$=90^{\circ}$, non-hydrogen atomic volume $=18.3 \AA^{3}, \rho_{\text {calc }}=$ $1.226 \mathrm{~g} / \mathrm{cm}^{-3}, 26627$ reflections were measured, 3896 unique reflections, resolution $=28.49-0.95 \AA$, completeness $(\%)=97.1, \mathrm{R}$ (int) $(\%)=0.0827, \mathrm{I} / \sigma=12.36,\left(\mathrm{R}_{\text {int }}=\Sigma \mid \mathrm{I}-\right.$ $\langle\mathrm{I}\rangle \mid / \Sigma \mathrm{I})$. The refinement converged to $\mathrm{R}_{1}=\Sigma|| \mathrm{F}_{\mathrm{o}}|-| \mathrm{F}_{\mathrm{c}}|| /$ $\Sigma\left|\mathrm{F}_{\mathrm{o}}\right|=0.0576$ for 3142 reflections $\mathrm{F}_{\mathrm{o}}>4 \sigma$ and 0.0782 for all 3896 data, $\mathrm{wR}_{2}=\left[\Sigma \mathrm{w}\left(\mathrm{F}_{\mathrm{o}}^{2}-\mathrm{F}_{\mathrm{c}}^{2} / \Sigma \mathrm{w}\left(\mathrm{F}_{\mathrm{o}}^{2}\right)^{2}\right]^{1 / 2}=0.1579\right.$ for 3896 data and 2/676 parameters, goodness of fit is 1.034 . The structure has been submitted to Cambridge Structure data base with CCDC number 603484.

Acknowledgments We thank Dr. F. Huth (bioLeads, Heidelberg) for the HRMS measurement, Mr. R. Machinek for the NMR spectra, Dr. H. Frauendorf for the mass spectra, Mrs. F. Lissy for microbiological work and Mrs. N. Sieck for technical support during purification. We thank Prof. H. H. Fiebig (Oncotest, Freiburg) for the determination of the cytotoxicity. This work was supported by a grant from the Bundesministerium für Bildung and Forschung (BMBF, grant 03F0346A). S. F. is thankful to the DAAD for a research grant.

\section{References}

1. Maehr H, Liu CM, Palleroni NJ, Smallheer J, Todaro L, Williams L, Blount JF. Microbial products. VIII. Azinothricin, a novel hexadepsipeptide antibiotic. J Antibiot 39: 17-25 (1986)

2. a) Sakai Y, Yoshida T, Tsujita T, Ochiai K, Agatsuma T, Saitoh Y, Tanaka F, Akiyama T, Akinaga S, Mizukami T. GE3, a novel hexadepsipeptide antitumor antibiotic, produced by Streptomyces sp. I. Taxonomy, production, isolation, physico-chemical properties, and biological activities. J Antibiot 50: 659-664 (1997)

b) Agatsuma T, Sakai Y, Mizukami T, Saitoh Y. GE3, a novel hexadepsipeptide antitumor antibiotic produced by Streptomyces sp. II. Structure determination. J Antibiot 50: 704-708 (1997)

3. Graefe U, Schlegel R, Ritzau M, Ihn W, Dornberger K,
Stengel C, Fleck WF, Gutsche W, Haertl A, Paulus EF. Aurantimycins, new depsipeptide antibiotics from Streptomyces aurantiacus IMET 43917: Production, isolation, structure elucidation, and biological activity. J Antibiot 48: 119-125 (1995)

4. Hale KJ, Cai J, Manaviazar S, Peak SA. Synthetic studies on the azinothricin family of antibiotics. 4. Enantioselective synthesis of the northern half of antitumor antibiotics A83586C and citropeptin. Tetrahedron Lett 36: 6965-6968 (1995)

5. Inagaki T, Abe Y. Antiulcer antibiotics. Jpn Kokai Tokkyo Koho JP 11269197 A2 19991005 (1999)

6. Fujiwara A, Abe Y, Inagaki K. Compounds for promoting wound healing. Jpn Kokai Tokkyo Koho JP 09263544 A2 19971007 (1997)

7. Inagaki KY, Abe A, Fujiwara A. Antiinflammatory drugs. Jpn Kokai Tokkyo Koho JP 09040559 A2 19970210 (1997)

8. Maskey RP, Asolkar RN, Kapaun E, Wagner-Döbler I, Laatsch H. Isolation of phytotoxic arylethylamides from limnic bacteria using microalgae. J Antibiot 55: 643-649 (2002)

9. Laatsch H. AntiBase 2006, A Natural Products Database for Rapid Structure Determination. Chemical Concepts, Weinheim 2006; see Internet http://www.gwdg.de/ ucoc/ laatsch/

10. Smitka TA, Deeter JB, Hunt AH, Mertz FP, Ellis RM, Boeck LD, Yao RC. A83586C, a new depsipeptide antibiotic. J Antibiot 41: 726-733 (1988)

11. Nakagawa M, Hayakawa Y, Furihata K, Seto H. Structural studies on new depsipeptide antibiotics, variapeptin and citropeptin. J Antibiot 43: 477-484 (1990)

12. Wu SJ, Fotso S, Li F, Qin S, Kelter G, Fiebig HH, Laatsch H. $N$-Carboxamido-staurosporine and selina-4(14),7(11)diene-8,9-diol, new metabolites from a marine Streptomyces sp. J Antibiot, in press

13. Sheldrick GM. SADABS. University of Goettingen (1999)

14. Sheldrick GM. Phase annealing in SHELX-90/96: direct methods for larger structures. Acta Crystallogr A 46: 467-473 (1990)

15. Sheldrick GM, Schneider TR. SHELXL: High resolution refinement. Methods Enzymol 277: 319-341 (1997) 